\title{
Outdoor thermal comfort by different heat mitigation strategies- A review
}

\author{
Mohammad Taleghani ${ }^{1}$ \\ University of Salford, Manchester, UK
}

\begin{abstract}
Due to the ongoing global warming, heat mitigation strategies are becoming implemented through practice and simulations. These efforts aim to make the cities that are dealing with the urban heat island more livable. The effect of heat mitigation strategies on climate condition and energy consumption have been studied and compared, previously. In this paper, the effect of these strategies on human thermal comfort in urban open spaces is reviewed. Specifically, the review is focused on vegetation (in the form of parks, street trees, green roofs and green walls), and highly reflective materials (on roof and on the ground level) as the most common strategies for improving the thermal conditions in cities. Several studies done by simulation or through field measurement in different countries are described. The most important finding of the review is the fact that although highly reflective materials reduce air temperature in urban open spaces, they increase the re-radiation of sun to the pedestrians. Therefore, vegetation is a better choice for improving thermal comfort in the pedestrian level.
\end{abstract}

\section{Keywords}

Outdoor thermal comfort; vegetation; highly reflective surfaces; urban heat island

\section{Introduction}

The air temperature in most of the cities are significantly higher than their rural areas. This phenomena which is called urban heat island (UHI) causes negative issues for urban settlers. UHI was first identified by Luck Howard, a meteorologist who measured the weather in London area for forty years (1801-1841) [1]. The UHI happens throughout the year, but it is stronger during the night when heat is absorbed by the urban surfaces with high heat capacity materials (e.g. asphalt and concrete). Apart the heat capacity of man-made materials, urban canyons reduce natural ventilation and therefore heat traps in cities. The intensity of the UHI is also related to the size and population of the city [2-5]. Oke [2] showed that UHI is approximately proportional to the fourth root of the population. This shows with the increase of urban settlers, more people are in prone to UHI. Since 2008, more than half of the world's population live in cities [6]. But, what are the consequences of UHI for citizens?

\footnotetext{
${ }^{1}$ Corresponding Author:

Mohammad Taleghani

Email: m.taleghani@salford.ac.uk
} 
Higher air temperature has direct and indirect effects. The most direct effect of UHI is lower thermal comfort of people in urban spaces, where there is no access to air conditioning systems [7-11]. UHI indirectly increases energy consumption for cooling [12,13], reduces the air quality in cities [14-18], and threats the ecosystem by warmer water flowing from the cities $[19,20]$.

As heat waves are the first natural cause of mortality [5, 21-25], this research focuses on the impact of UHI on thermal comfort of people in urban open spaces. During a two week heat wave in August 2003, 70,000 people passed away [22]. Heat related mortality occurs when human body absorbs more heat than it dissipates. This is more serious for elderly and people with cardio-vascular problems who have weaker thermoregulatory body system [25]. Several studies have shown strong correlations between heat waves and excess mortality $[21,23,26]$. In this way, making cities cooler seems vital for public health.

Thermal comfort is associated with environmental (air temperature, radiant temperature, wind speed, and relative humidity) and personal (clothing and metabolism) factors [7, 27-30]. Several studies have shown that radiation plays the greatest role on thermal comfort [28, 31-34]. In [35-40], the impact of urban morphology and different heat mitigation strategies on urban climate have been reviewed. Due to the significant role of radiation on thermal comfort, in this paper we focus on the heat mitigation strategies that reduce net radiation in urban spaces. Equation 1 describes the variables affecting net radiation [41]:

$\mathrm{Rn}=\mathrm{H}+\mathrm{LE}+\mathrm{G}$

where $\mathrm{Rn}$ is net radiation, $\mathrm{H}$ is sensible heat flux, $\mathrm{LE}$ is latent heat flux, and $\mathrm{G}$ is soil heat flux (all variables are in $\mathrm{W} / \mathrm{m}^{2}$.

Several heat mitigation strategies have been implemented in different cities to reduce net radiation. Theoretically, the lower net radiation, the lower heat in cities. Based on this principal vegetation and reflective materials are widely used as passive methods to mitigate heat in urban spaces. Here we review these strategies extensively. Therefore, the paper will focus on the most recent studies that have successfully implemented heat mitigation strategies in the world. Specifically, vegetation and high albedo materials will be studied in different form of application. The reviewed studies have used different methods (i.e. simulation and measurements).

\section{Heat mitigation strategies}

\subsection{Vegetation in different forms}

Vegetation reduces heat in three ways:

a) by evapotranspiration,

b) by reflecting the sun because of the higher albedo of the leaves compared to man-made dark materials;

c) by blocking the solar radiation.

Vegetation has been used in various ways in cities. From a large to local scale, we can see vegetation in cities as parks, street trees, grass yards, and green roofs. 


\subsubsection{Parks}

Parks probably have the biggest cooling effect for citizens. Hwang et al. [42] in a study on 10 parks in the tropical climate of Singapore showed that the air temperature in parks could be 8 to $12{ }^{\circ} \mathrm{C}$ cooler than outside. They showed the parks with more shading are more thermally comfortable. This finding becomes more important when we consider that the minimum temperature in Singapore is $23^{\circ} \mathrm{C}$ [43].

Looking at the hot and dry climate, parks seem very vital for public health. Feysia et al. [44] by measuring air temperature and humidity in 21 parks in Addis Ababa showed that plant types, NDVI (Normalized Difference Vegetation Index), and shape and size of the parks have appreciable correlations with the cooling effect. The maximum park cooling effect $(\mathrm{PCl})$ they found was $6.72{ }^{\circ} \mathrm{C}$. Moreover, they measured the maximum spatial park cooling distance ( $P C D)$, which was $240 \mathrm{~m}$. This means the cooling effect of a park could be felt up to $240 \mathrm{~m}$ far from the park. By comparing different plants (i.e. Acacia tortilis, Eucalyptus spp., Grevillea robusta, Cupressus lusitanica and Olea), they showed Eucalyptus spp has the most cooling effect; while Grevillea and Cupressus have the minimum effect.

Spronken and Oke [45] studied the PCl in two cities with different climates, Vancouver (BC) and Sacramento (CA). They showed the maximum cooling effect in Vancouver was $5{ }^{\circ} \mathrm{C}$; while irrigation of the park in Sacramento (with a hotter climate) makes the $\mathrm{PCl}$ up to $7^{\circ} \mathrm{C}$. They found out the trees are the most important element for the cooling effect of the parks during the day. This was due to the shading and evapotranspiration effect of the trees. During the night, the amount of moisture and surface geometry of the parks were the most important causes of $\mathrm{PCl}$.

Vidrih and Medved [46] considered the effect of leaf area index (LAI) on the cooling effect of parks in Slovenia. By using a 3D CFD model, they showed that with the LAI of 3.16 (equal to 45 trees per hectare), air temperature reduction is up to $4.8^{\circ} \mathrm{C}$. In a more comprehensive and empirical study done by Hardwick et .al [47], the effect of different levels of LAI on different micrometeorological variables were studied in Malaysia. They found a strong correlation between LAI and the mean daily maximum air and soil temperatures. They also showed a higher cooling effect associated with higher relative humidity under vegetation canopies with higher LAl. They also showed a canopy with $33.7 \mathrm{~m}$ height is $6.5^{\circ} \mathrm{C}$ cooler than oil palm plantations with $5.3 \mathrm{~m}$ height. Figure 1 shows the surface temperature of the park of the campus of Portland State University compared to the buildings. 

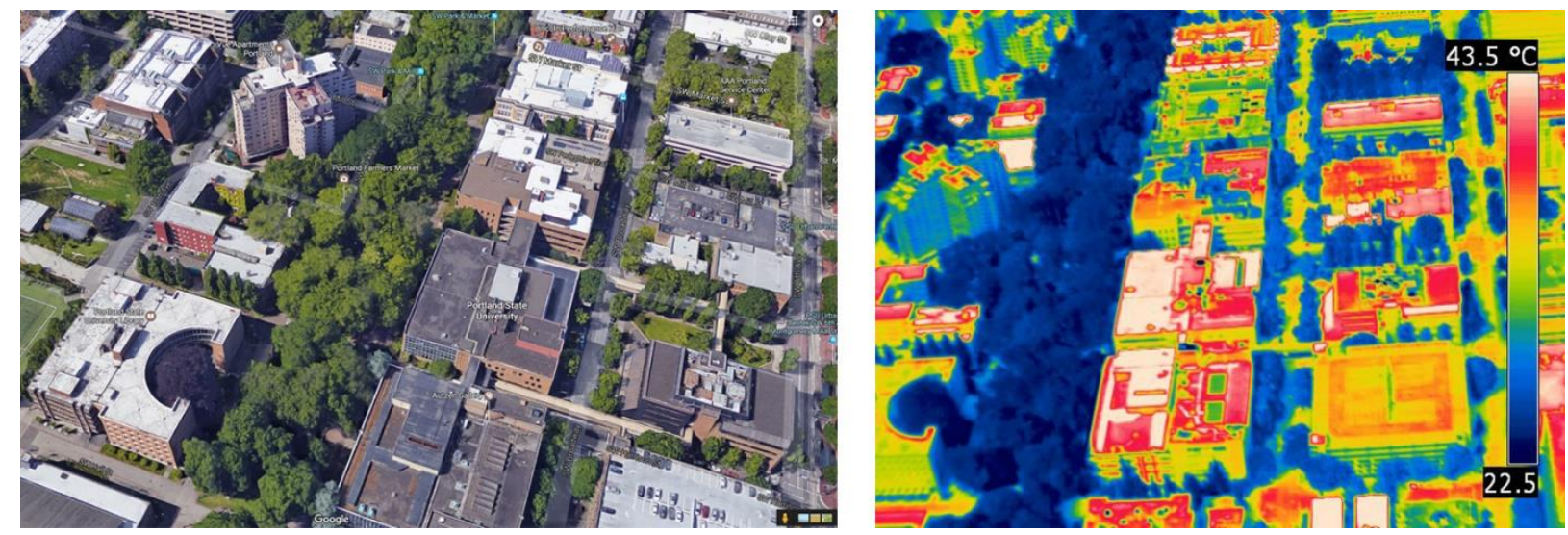

Figure 1: The surface temperature of a park compared to the surrounding buildings. Portland State University, OR, USA. 23 August 2011.Image after [48]. Thermal image is from the archive of David J. Sailor.

\subsubsection{Street trees}

Street trees have several environmental benefits for urban citizens. Because of our focus on thermal condition and comfort in urban open spaces, we review the most important investigations on thermal comfort. Coutts et al. [49] measured three east-west streets during heat waves in the temperature climate of Melbourne, Australia. They considered the Universal Thermal Climate Index (UTCI) for the calculation of outdoor thermal comfort within the tree canopies. The maximum UTCI reduction by the trees were $6{ }^{\circ} \mathrm{C}$. Moreover, they reported that the maximum air temperature reduction was $1.5^{\circ} \mathrm{C}$. A similar research done in Melbourne showed that Platanus trees led to a PET reduction of $6.6^{\circ} \mathrm{C}$ during a heat wave.

Regarding the cooling effect of different tree species, Doick and Hutchings [50] discuss that the lower the foliage temperature, the greater cooling effect. Monteith and Unsworth [51] argue that the leaf temperature depends on anatomical (e.g. LAl and size) and physiological (e.g. transpiration and stomatal conductance) factors. In this way, the water status (i.e. irrigation) will have a significant effect on the ability of a tree to evaporate water through the stomata of its leaves [52].

Another advantage of street trees is their impact on their adjacent. Mayer et. al [53] showed that trees reduce mean radiant temperature $\left(T_{\mathrm{mrt}}\right)$ even for the buildings that are not shaded by the trees. In the city of Freiburg (Germany), they showed that trees reduce $\mathrm{T}_{\text {mrt }}$ up to $29 \%$ at the not directly shaded site. This amount of radiation reduction is very important for the improvement of pedestrian's thermal comfort. This is mainly due to the dependency of thermal comfort on $T_{m r t}[28,32]$. This reduction of radiation can improve the thermal comfort of people inside the adjacent buildings. For instance, Heisler [54] showed that a sugar maple tree reduced irradiance by its shading effect up to $80 \%$ in summer (when in leaf) and $40 \%$ in winter (leafless). 


\subsubsection{Green roofs}

Santamouris [55] reviewed the impact of green roofs on UHI. By comparing different simulation studies, he found out that green roofs can reduce the average air temperature between 0.3 and $3.0 \mathrm{~K}$ when applied on urban scale. Depending on the adoption scale, the cooling effect varies. Smith and Roebber [56] studied the adoption of green roofs during a typical summer day in Chicago, Illinois. They used the Weather Research and Forecasting Model (ARW) [57] coupled with an urban canopy model. In accordance with [55], they showed that the air temperature during 19:00-23:00 is reduced up to $2-3^{\circ} \mathrm{C}$ because of the higher albedo of the vegetative roofs, and the evapotranspiration effect. Figure 2 shows a green roof with its layers.

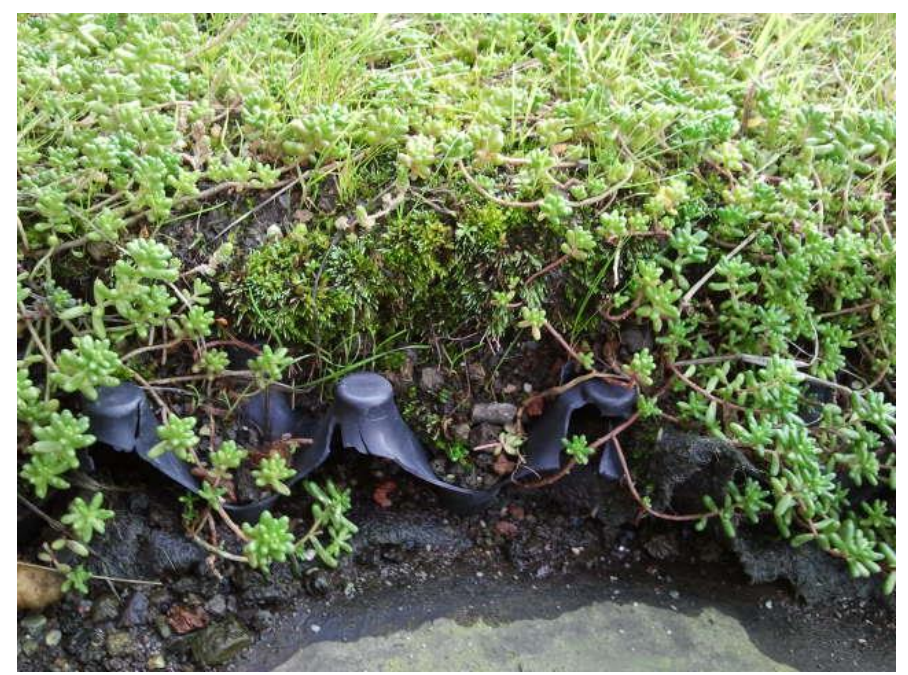

Figure 2: A green roof with different layers at Delft University of Technology, Delft, the Netherlands.

Sun et al. [58] investigated the temperature reduction over a roof $(2.5 \mathrm{~m})$ in Taipei. They showed the cooling effect of the green roof was more significant during day time. Comparing the green roof with a similar black roof, the green roof reduced the ambient air temperature $0.26{ }^{\circ} \mathrm{C}$ in average. The maximum cooling effect was reported $1.6^{\circ} \mathrm{C}$.

Chen et al. [59] performed simulations on the impact of high rise buildings green roofs on the pedestrian height $(1.5 \mathrm{~m})$ thermal condition in Tokyo, Japan. For the simulations, they used coupled simulations of convection, radiation, and conduction [60]. They showed that the cooling effect of green roofs on pedestrians are negligible due to the height of the building roofs. Likewise, Taleghani et al. [61] studied the effect of different heat mitigation strategies on pedestrians' comfort in a Los Angeles neighborhood during a heat wave. They showed that the green roofs at the height $6 \mathrm{~m}$ (two-story dwellings) did not improve street level thermal comfort. The simulated neighborhood area was $0.3 \mathrm{~km}^{2}$. Comparing this area with the study on Chicago [56] $\left(606 \mathrm{~km}^{2}\right)$, it could be said that the size of the modification significantly affects heat mitigation. 


\subsubsection{Green walls}

Vegetation is also used on facades, as green walls. This class of heat mitigation strategy affects building indoor environment and outdoor. Bartfelder and Köhler [62] measured the air temperature in front of a bare and a green wall in Berlin (Germany). They showed that the cooling impact of the green wall depends on the outdoor temperature. They observed that the cooling effect of the green wall was $0.4{ }^{\circ} \mathrm{C}$ and $5.8^{\circ} \mathrm{C}$ during the cool and hot days, respectively.

Wong et al. [63] investigated the surface temperature of eight different green wall systems. They showed that the average surface temperature of green walls were $4.36{ }^{\circ} \mathrm{C}$ cooler than bare walls on $21^{\text {st }}$ of June in Singapore. They also measured the ambient temperature in front of the walls. They observed temperature reductions up to $3.33^{\circ} \mathrm{C}(0.15 \mathrm{~m}$ away $)$ and hardly any effect was felt at the distance of $0.60 \mathrm{~m}$.

In [48], the microclimate of two courtyards were measured during summer 2013. The walls of one courtyard was covered with red bricks, and the other with vegetation (Fig 3). They measured air temperature at the center of the courtyards for one week. They observed that the courtyard with green walls was up to $4.7^{\circ} \mathrm{C}$ cooler than the bare one (at 16:30 PM).
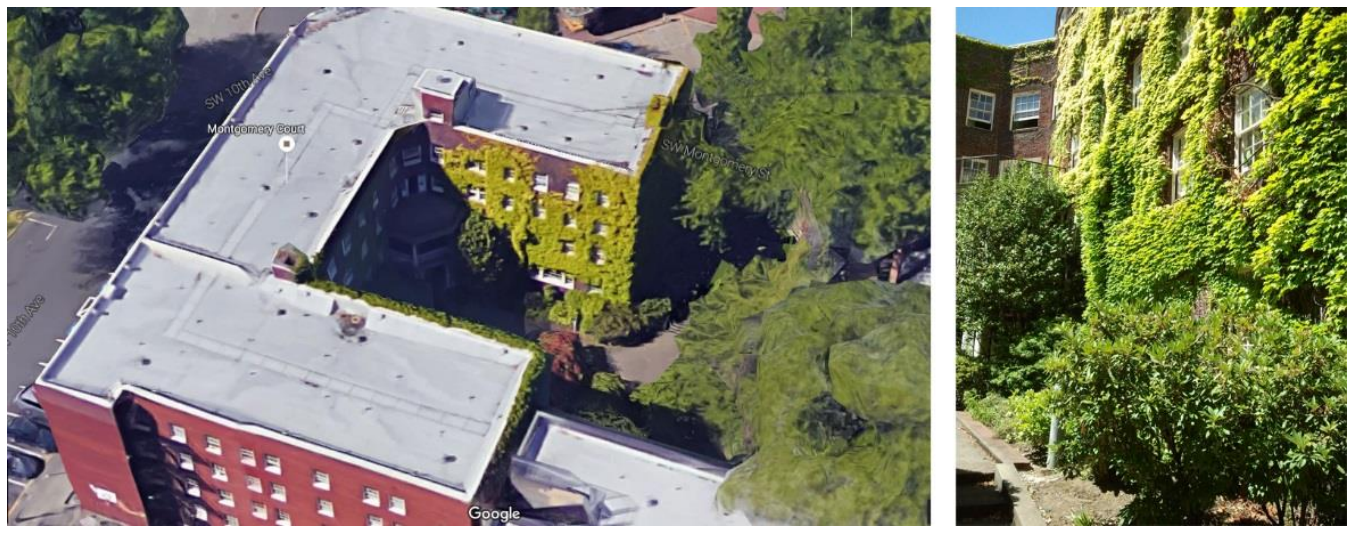

Figure 3: A courtyard building with green walls, at the campus of Portland State University (Portland, OR, USA).

\subsection{High albedo materials}

\subsubsection{White (reflective) roofs}

Reflective and white roofs have several benefits for the urban in indoor building thermal condition. Several studies have shown the impact of white roofs on indoor cooling energy saving in summer time $[13,16,64,65]$. Others showed reduced thermal stress (and consequently higher lifetime) of cool roofs compared to the other roof types [66-69]. Furthermore, white roofs improve indoor thermal comfort for the occupants [70,71]. Nevertheless, we will focus on the impact of white and reflective roofs on microclimate and outdoor thermal comfort. 
White roofs reflect most of the short wave radiation from the sun to the sky. This leads to lower absorption of heat by the roof. During the summer time, roofs receive the largest portion of solar radiation (due to the high altitude of the sun) [72]. The percentage of re-radiating the sun depends on the albedo of the roof surface. Table 1 demonstrates the albedo of highly reflective roof materials.

Table 1: Radiative properties of high albedo materials (Table after [73-75]).

\begin{tabular}{|l|l|l|}
\hline Surface material & Albedo $(\alpha)$ & Emissivity $(\varepsilon)$ \\
\hline White paper & 0.75 & 0.95 \\
\hline Plaster (fresh) & 0.93 & 0.91 \\
\hline Bright aluminum foil & 0.85 & 0.04 \\
\hline Green pigment & 0.73 & 0.95 \\
\hline Gravel & 0.72 & 0.28 \\
\hline
\end{tabular}

Almeria (Spain) is one of the best examples of implementing white roofs ( $26,000 \mathrm{ha})$. The average ambient air temperature in this city is reported $0.3{ }^{\circ} \mathrm{C}$ cooler than its rural area [76]. Figure 4 shows an aerial view of the city with its white surfaces.

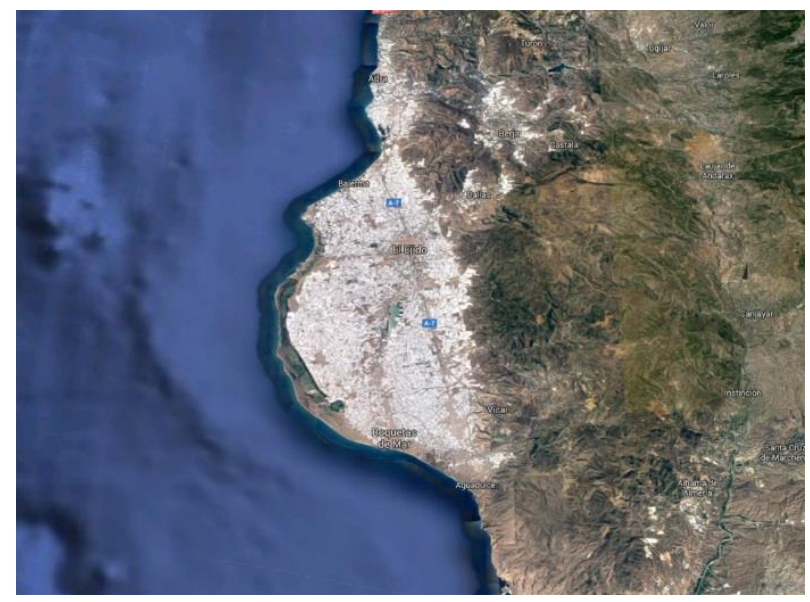

Figure 4: Almeria (Spain) with white surfaces [77].

Rosenfeld et al. [78] simulated $100,000 \mathrm{~km}^{2}$ in Los Angeles to adopt cool roofs (albedo improvement from 0.25 to 0.75 for the flat roofs, and from 0.25 to 0.60 for sloped roofs). The maximum cooling effect was reported $3.0^{\circ} \mathrm{C}$ at $15: 00$. It was also found out that the peak ambient air temperatures were reduced 2 to $4{ }^{\circ} \mathrm{C}$.

Regarding the impact of cool roofs on microclimate, Doulos et al. [79] compared 93 pavement materials in Athens (Greece) during August 2001. They used thermal photography technic to observe the surface temperature differences. They showed the surface temperature of a white marble pavement could be up to $19{ }^{\circ} \mathrm{C}$ cooler than black granite. This cooling effect can significantly affect the local microclimate. 
Taleghani et al [48] measured the mean radiant temperature and air temperature above two different roof surfaces. The measurement campaigns were done at the campus of Portland State University (OR, USA) during summer 2013. They compared a black roof (albedo 0.37) with a white roof (albedo 0.91). It was found that the white roof led to $2.9^{\circ} \mathrm{C}$ higher $\mathrm{T}_{\text {mrt }}$ above the surface, but reduced $1.3^{\circ} \mathrm{C} \mathrm{T}_{\mathrm{a}}$. While the roof is not a commonly used area, it should be noted that this increase of $\mathrm{T}_{\text {mrt }}$ by the high albedo surface can cause thermal discomfort above the roof.

\subsubsection{Reflective ground pavements}

A large portion of urban surfaces is covered by low albedo pavements $[78,80]$. In [61], $T_{m r t}$ and $T_{a}$ at $1.5 \mathrm{~m}$ height were simulated in a residential neighborhood during summer 2014 . It was shown that the temperatures above the asphalt pavement was the highest in the neighborhood. They showed that $T_{\mathrm{mrt}}$ above an unshaded asphalt could be $30^{\circ} \mathrm{C}$ higher than vegetation. This amount of re-radiation from the asphalt pavement caused discomfort for the pedestrians at the sidewalks. Figure 5 shows how the surface temperature of an asphalt roof can be risen by sun.

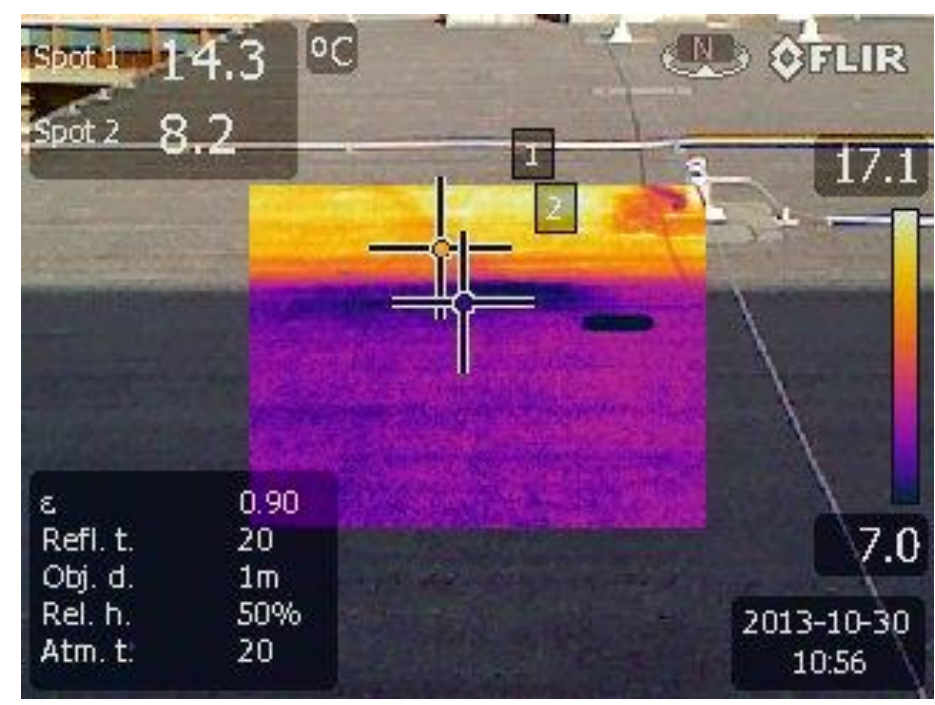

Figure 5: The comparison of the surface temperature of shaded and unshaded asphalt pavement at 10:56 on 30 October 2013.

In [81], the effect of ground surface albedo on the microclimate and pedestrians' thermal comfort were studied. Micrometeorological simulations were performed to see the impact of improving the albedo from 0.1 to 0.3 and 0.5. The simulated area was an urban square in Toronto, Canada. It was found that the increase of albedo made the square 0.5 and $1.0^{\circ} \mathrm{C}$ cooler at $15: 00$ (by albedo 0.3 and 0.5 , compared to 0.1 albedo, respectively). Although the increase of albedo reduced $T_{a}$, it increased $T_{m r t}$ and caused discomfort for the pedestrians.

Santamouris et al. [36] through "the largest application of cool pavements in urban areas in the world" investigated the impact of $4500 \mathrm{~m}^{2}$ reflective pavements in Athens. The maximum cooling effect that 
they observed was $1.9 \mathrm{~K}$ during a summer day. By using a thermal camera, they also showed that the surface temperature was decreased by $12 \mathrm{~K}$. They concluded that the cool pavement improved significantly the pedestrians' thermal comfort in an urban open space.

Most of the reviewed studies showed that the asphalt pavements cause discomfort for pedestrians. Carnielo and Zinzi [82] tested asphalt pavements with different surface colors. They measured the surface temperatures in Rome, Italy, during August 2011. Five painted asphalt were compared with the conventional asphalt at the campus of Italian National Agency for New Technologies. The maximum surface temperature differences between the control asphalt (dark) and the colored ones were 6.2, 7.8, $7.9,10.0$, and $19.3{ }^{\circ} \mathrm{C}$, for the red, green, blue, grey and white asphalts, respectively. This experiment showed how a simple change in surface color can cause significant cooler surface temperature; while keeping the rest of the pavement properties (such as heat capacity) the same.

\section{Conclusions}

This paper reviewed the impact of different heat mitigation strategies on the pedestrians' thermal comfort in the context of urban and microclimate. It should be noted that the magnitude of UHI varies in different climates. Consequently, in each climate, a specific heat mitigation strategy is needed. Most of the previous studies have investigated the changes of meteorological variables (such as air temperature deviations) by heat mitigation strategies. Among different heat mitigation strategies, vegetation and high albedo (reflective) surfaces as solutions for improving outdoor thermal comfort in urban spaces were investigated in this paper. Vegetation was studied in the forms of parks, street trees, green roofs and green walls. High albedo materials were then studied while they are used on the roofs (as white roofs) and on the ground surfaces. Through several examples in different countries and climates, it was shown that urban surfaces play an important role on the thermal comfort of pedestrians. Vegetation and high albedo surfaces showed appreciable reduction of air temperatures within urban open spaces. However, mean radiant temperature affects human thermal comfort more than the other meteorological variables. Therefore, using high albedo materials on the ground surface causes reradiation of solar radiation to pedestrians and leads to thermal discomfort (in spite of reducing air temperature). So, this paper concludes that using vegetation in urban open spaces is a better choice for improving thermal comfort in the pedestrian level. Given the importance of the UHI phenomena, it is recommended for future research projects to investigate the effect of heat mitigation strategies in urban scale on local pedestrian comfort. Furthermore, as UHI varies in different climates, finding a correlation between heat mitigation strategies and different climates and latitudes would be very interesting to investigate. 


\section{Appendix}

Table 2: classification of the reviewed studies.

\begin{tabular}{|c|c|c|c|c|c|}
\hline Strategy & Method & Reference & $\begin{array}{l}\text { Study } \\
\text { year }\end{array}$ & $\begin{array}{l}\text { Studied } \\
\text { climate }\end{array}$ & Main finding \\
\hline \multirow[t]{16}{*}{ Vegetation } & \multirow[t]{4}{*}{ Parks } & {$[42]$} & 2015 & $\begin{array}{l}\text { Singapore, } \\
\text { Singapore }\end{array}$ & 8 to $12{ }^{\circ} \mathrm{C}$ cooler air temperature \\
\hline & & [44] & 2014 & $\begin{array}{l}\text { Addis } \\
\text { Ababa, } \\
\text { Ethiopia }\end{array}$ & Maximum $\mathrm{PCl}$ of $6.72{ }^{\circ} \mathrm{C}$ \\
\hline & & {$[45]$} & 1998 & $\begin{array}{l}\text { Vancouver, } \\
\text { BC, Canada } \\
\text { Sacramento, } \\
\text { CA, USA }\end{array}$ & $\begin{array}{l}\text { Maximum cooling effect of } 5^{\circ} \mathrm{C} \text { in } \\
\text { Vancouver; } \\
\mathrm{PCl} \text { up to } 7^{\circ} \mathrm{C} \text { in Sacramento }\end{array}$ \\
\hline & & {$[46]$} & 2013 & Slovenia & $\begin{array}{l}\text { Air temperature reduction up to } 4.8 \\
{ }^{\circ} \mathrm{C}\end{array}$ \\
\hline & \multirow[t]{6}{*}{$\begin{array}{l}\text { Street } \\
\text { trees }\end{array}$} & [49] & 2016 & $\begin{array}{l}\text { Melbourne, } \\
\text { Australia }\end{array}$ & $\begin{array}{l}\text { UTCI reduction of } 6^{\circ} \mathrm{C} \text {; air } \\
\text { temperature reduction of } 1.5^{\circ} \mathrm{C}\end{array}$ \\
\hline & & {$[50]$} & 2013 & UK cities & $\begin{array}{l}\text { the lower the foliage temperature, } \\
\text { the greater cooling effect }\end{array}$ \\
\hline & & {$[51]$} & 2013 & & $\begin{array}{l}\text { Irrigation has a significant effect on } \\
\text { the ability of a tree to evaporate }\end{array}$ \\
\hline & & {$[53]$} & 2008 & $\begin{array}{l}\text { Freiburg, } \\
\text { Germany }\end{array}$ & $\begin{array}{l}\text { Trees reduce } T_{\text {mrt }} \text { up to } 29 \% \text { at the } \\
\text { not directly shaded site }\end{array}$ \\
\hline & & [54] & 1986 & $\begin{array}{l}\text { State } \\
\text { College, PA, } \\
\text { USA }\end{array}$ & $\begin{array}{l}\text { A sugar maple tree reduced } \\
\text { irradiance by its shading effect up to } \\
80 \% \text { in summer (when in leaf) and } \\
40 \% \text { in winter (leafless) }\end{array}$ \\
\hline & & [47] & 2015 & Malaysia & $\begin{array}{l}6.5^{\circ} \mathrm{C} \text { cooler air temperature in a } \\
\text { vegetated canopy }\end{array}$ \\
\hline & \multirow[t]{5}{*}{$\begin{array}{l}\text { Green } \\
\text { roofs }\end{array}$} & {$[55]$} & 2014 & & $\begin{array}{l}\text { Green roofs can reduce the average } \\
\text { air temperature between } 0.3 \text { and } \\
3.0 \mathrm{~K} \text { when applied on urban scale }\end{array}$ \\
\hline & & {$[56]$} & 2011 & $\begin{array}{l}\text { Chicago, } \\
\text { Illinois, USA }\end{array}$ & $\begin{array}{l}\text { The air temperature during } 19: 00- \\
23: 00 \text { is reduced up to } 2-3^{\circ} \mathrm{C}\end{array}$ \\
\hline & & {$[58]$} & 2012 & $\begin{array}{l}\text { Taipei, } \\
\text { Taiwan }\end{array}$ & $\begin{array}{l}\text { A green roof reduced the ambient } \\
\text { air temperature } 0.26^{\circ} \mathrm{C} \text { in average }\end{array}$ \\
\hline & & [59] & 2009 & $\begin{array}{l}\text { Tokyo, } \\
\text { Japan }\end{array}$ & $\begin{array}{l}\text { The cooling effect of high rise } \\
\text { buildings with green roofs on } \\
\text { pedestrians are negligible due to the } \\
\text { height of the roofs }\end{array}$ \\
\hline & & [61] & 2016 & $\begin{array}{l}\text { Los Angeles, } \\
\text { CA, USA }\end{array}$ & $\begin{array}{l}\text { The green roofs at the height } 6 \mathrm{~m} \\
\text { (two-story dwellings) did not } \\
\text { improve street level thermal } \\
\text { comfort }\end{array}$ \\
\hline & $\begin{array}{l}\text { Green } \\
\text { walls }\end{array}$ & {$[62]$} & 1987 & $\begin{array}{l}\text { Berlin, } \\
\text { Germany }\end{array}$ & $\begin{array}{l}\text { The cooling effect of a green wall on } \\
\text { outdoor environment was } 0.4^{\circ} \mathrm{C} \text { and }\end{array}$ \\
\hline
\end{tabular}




\begin{tabular}{|c|c|c|c|c|c|}
\hline & & & & & $\begin{array}{l}5.8^{\circ} \mathrm{C} \text { during the cool and hot days, } \\
\text { respectively }\end{array}$ \\
\hline & & [63] & 2010 & $\begin{array}{l}\text { Singapore, } \\
\text { Singapore }\end{array}$ & $\begin{array}{l}\text { the average surface temperature of } \\
\text { green walls were } 4.36{ }^{\circ} \mathrm{C} \text { cooler than } \\
\text { bare walls }\end{array}$ \\
\hline & & [48] & 2014 & $\begin{array}{l}\text { Portland, } \\
\text { OR, USA }\end{array}$ & $\begin{array}{l}\text { A courtyard with green walls was up } \\
\text { to } 4.7^{\circ} \mathrm{C} \text { cooler than a bare one (at } \\
16: 30 \mathrm{PM} \text { ) }\end{array}$ \\
\hline \multirow[t]{7}{*}{$\begin{array}{l}\text { High } \\
\text { albedo } \\
\text { materials }\end{array}$} & \multirow[t]{4}{*}{$\begin{array}{l}\text { White } \\
\text { (reflective) } \\
\text { roofs }\end{array}$} & [76] & 2008 & $\begin{array}{l}\text { Almeria, } \\
\text { Spain }\end{array}$ & $\begin{array}{l}\text { The average ambient air } \\
\text { temperature in Almeria is reported } \\
0.3^{\circ} \mathrm{C} \text { cooler than its rural area. }\end{array}$ \\
\hline & & [83] & 1997 & $\begin{array}{l}\text { Los Angeles, } \\
\text { CA, USA }\end{array}$ & $\begin{array}{l}\text { The peak ambient air temperature in } \\
\text { the city was reduced } 2 \text { to } 4{ }^{\circ} \mathrm{C} \text { by } \\
\text { adopting } 100,000 \mathrm{~km}^{2} \mathrm{cool} \text { roofs }\end{array}$ \\
\hline & & [79] & 2004 & $\begin{array}{l}\text { Athens, } \\
\text { Greece }\end{array}$ & $\begin{array}{l}\text { The surface temperature of a white } \\
\text { marble pavement could be up to } 19 \\
{ }^{\circ} \mathrm{C} \text { cooler than black granite }\end{array}$ \\
\hline & & {$[48]$} & 2014 & $\begin{array}{l}\text { Portland, } \\
\text { OR, USA }\end{array}$ & $\begin{array}{l}\text { A white roof (albedo } 0.91 \text { ) led to } 2.9 \\
{ }^{\circ} \mathrm{C} \text { higher } \mathrm{T}_{\text {mrt }} \text { above the surface than } \\
\text { a black roof (albedo } 0.37 \text { ), but } \\
\text { reduced } 1.3^{\circ} \mathrm{C} \text { air temperature }\end{array}$ \\
\hline & \multirow[t]{3}{*}{$\begin{array}{l}\text { Reflective } \\
\text { ground } \\
\text { pavements }\end{array}$} & [61] & 2016 & $\begin{array}{l}\text { Los Angeles, } \\
\text { CA, USA }\end{array}$ & $\begin{array}{l}T_{\text {mrt }} \text { above an unshaded asphalt } \\
\text { could be } 30^{\circ} \mathrm{C} \text { higher than } \\
\text { vegetation }\end{array}$ \\
\hline & & [36] & 2013 & $\begin{array}{l}\text { Athens, } \\
\text { Greece }\end{array}$ & $\begin{array}{l}\text { Air temperature reduction of } 1.9 \mathrm{~K} \\
\text { and surface temperature reduction } \\
\text { of } 12 \mathrm{~K} \text { by application of } 4500 \mathrm{~m}^{2} \\
\text { cool pavements }\end{array}$ \\
\hline & & [82] & 2013 & Rome, Italy & $\begin{array}{l}\text { The maximum surface temperature } \\
\text { differences between the control } \\
\text { asphalt (dark) and the colored ones } \\
\text { were } 6.2,7.8,7.9,10.0 \text {, and } 19.3^{\circ} \mathrm{C} \text {, } \\
\text { for the red, green, blue, grey and } \\
\text { white asphalts, respectively }\end{array}$ \\
\hline
\end{tabular}




\section{References}

1. Howard, L., The climate of London, deduced from meteorological observations made in the metropolis and various places around it. 1833, London: Harvey and Darton.

2. Oke, T.R., City size and the urban heat island. Atmospheric Environment (1967), 1973. 7(8): p. 769-779.

3. Steeneveld, G.J., S. Koopmans, B.G. Heusinkveld, L.W.A. van Hove, and A.A.M. Holtslag, Quantifying urban heat island effects and human comfort for cities of variable size and urban morphology in the Netherlands. Journal of Geophysical Research: Atmospheres, 2011. 116(D20): p. n/a-n/a.

4. Adachi, S.A., F. Kimura, H. Kusaka, T. Inoue, and H. Ueda, Comparison of the Impact of Global Climate Changes and Urbanization on Summertime Future Climate in the Tokyo Metropolitan Area. Journal of Applied Meteorology and Climatology, 2012. 51(8): p. 1441-1454.

5. Hajat, S. and T. Kosatky, Heat-related mortality: a review and exploration of heterogeneity. J Epidemiol Community Health, 2010. 64(9): p. 753-60.

6. UN. United Nation Population Division. 2009.

7. Matzarakis, A. and B. Amelung, Physiological Equivalent Temperature as Indicator for Impacts of Climate Change on Thermal Comfort of Humans, in Seasonal Forecasts, Climatic Change and Human Health, M.C. Thomson, R. García Herrera, and M. Beniston, Editors. 2008, Springer.

8. Busch, J.F., A tale of two populations: thermal comfort in air-conditioned and naturally ventilated offices in Thailand. Energy and Buildings, 1992. 18(3-4): p. 235-249.

9. Kikegawa, Y., Y. Genchi, H. Kondo, and K. Hanaki, Impacts of city-block-scale countermeasures against urban heat-island phenomena upon a building's energy-consumption for airconditioning. Applied Energy, 2006. 83(6): p. 649-668.

10. Radhi, H. and S. Sharples, Quantifying the domestic electricity consumption for air-conditioning due to urban heat islands in hot arid regions. Applied Energy, 2013. 112(0): p. 371-380.

11. Lynn, B.H., T.N. Carlson, C. Rosenzweig, R. Goldberg, L. Druyan, J. Cox, S. Gaffin, et al., A Modification to the NOAH LSM to Simulate Heat Mitigation Strategies in the New York City Metropolitan Area. Journal of Applied Meteorology and Climatology, 2009. 48(2): p. 199-216.

12. Akbari, H. and S. Konopacki, Energy effects of heat-island reduction strategies in Toronto, Canada. Energy, 2004. 29(2): p. 191-210.

13. Akbari, H. and S. Konopacki, Calculating energy-saving potentials of heat-island reduction strategies. Energy Policy, 2005. 33(6): p. 721-756.

14. Taha, H., Urban Surface Modification as a Potential Ozone Air-quality Improvement Strategy in California: A Mesoscale Modelling Study. Boundary-Layer Meteorology, 2008. 127(2): p. 219239.

15. Taha, H., S. Douglas, and J. Haney, Mesoscale meteorological and air quality impacts of increased urban albedo and vegetation. Energy and Buildings, 1997. 25(2): p. 169-177.

16. Akbari, H., M. Pomerantz, and H. Taha, Cool surfaces and shade trees to reduce energy use and improve air quality in urban areas. Solar Energy, 2001. 70(3): p. 295-310.

17. Civerolo, K.L., G. Sistla, S.T. Rao, and D.J. Nowak, The effects of land use in meteorological modeling: implications for assessment of future air quality scenarios. Atmospheric Environment, 2000. 34(10): p. 1615-1621.

18. Li, J., M. Georgescu, P. Hyde, A. Mahalov, and M. Moustaoui, Achieving accurate simulations of urban impacts on ozone at high resolution. Environmental Research Letters, 2014. 9(11): p. 114019.

19. Mentens, J., D. Raes, and M. Hermy, Green roofs as a tool for solving the rainwater runoff problem in the urbanized 21st century? Landscape and Urban Planning, 2006. 77(3): p. 217-226. 
20. Onmura, S., M. Matsumoto, and S. Hokoi, Study on evaporative cooling effect of roof lawn gardens. Energy and Buildings, 2001. 33(7): p. 653-666.

21. Andersona, B.G. and M.L. Bell, Weather-Related Mortality, How Heat, Cold, and Heat Waves Affect Mortality in the United States. Epidemiology, 2009. 20(2): p. 205-213.

22. Robine, J.-M., S.L.K. Cheung, S. Le Roy, H. Van Oyen, C. Griffiths, J.-P. Michel, and F.R. Herrmann, Death toll exceeded 70,000 in Europe during the summer of 2003. Comptes Rendus Biologies, 2008. 331(2): p. 171-178.

23. Vanos, J.K., L.S. Kalkstein, and T.J. Sanford, Detecting synoptic warming trends across the US Midwest and implications to human health and heat-related mortality. International Journal of Climatology, 2014: p. n/a-n/a.

24. Sampson, N.R., C.J. Gronlund, M.A. Buxton, L. Catalano, J.L. White-Newsome, K.C. Conlon, M.S. O'Neill, et al., Staying cool in a changing climate: Reaching vulnerable populations during heat events. Global Environmental Change, 2013. 23(2): p. 475-484.

25. Metzger, K.B., K. Ito, and T.D. Matte, Summer heat and mortality in New York City: how hot is too hot? Environ Health Perspect, 2010. 118(1): p. 80-6.

26. Kalkstein, L., S. Greene, D. Mills, and J. Samenow, An evaluation of the progress in reducing heatrelated human mortality in major U.S. cities. Natural Hazards, 2011. 56(1): p. 113-129.

27. Taleghani, M., M. Tenpierik, S. Kurvers, and A. van den Dobbelsteen, A review into thermal comfort in buildings. Renewable and Sustainable Energy Reviews, 2013. 26(0): p. 201-215.

28. Höppe, P., The physiological equivalent temperature - $A$ universal index for the biometeorological assessment of the thermal environment. International Journal of Biometeorology, 1999. 43(2): p. 71-75.

29. Winslow, C.A., L.P. Herrington, and A.P. Gagge, Influence of physical work on physiological reactions to the thermal environment. american Journal of Physiology, 1941. 134: p. 664-681.

30. Kleerekoper, L., M. Taleghani, A. van den Dobbelsteen, and T. Hordijk, Urban measures for hot weather conditions in a temperate climate condition: A review study. Renewable and Sustainable Energy Reviews, In Press.

31. Höppe, P., Heat balance modelling. Experientia, 1993. 49(9): p. 741-746.

32. Taleghani, M., M. Tenpierik, A. van den Dobbelsteen, and D.J. Sailor, Heat in courtyards: A validated and calibrated parametric study of heat mitigation strategies for urban courtyards in the Netherlands. Solar Energy, 2014. 103: p. 108-124.

33. Thorsson, S., J. Rocklöv, J. Konarska, F. Lindberg, B. Holmer, B. Dousset, and D. Rayner, Mean radiant temperature - A predictor of heat related mortality. Urban Climate, 2014. 10, Part 2(0): p. 332-345.

34. Taleghani, M., L. Kleerekoper, M. Tenpierik, and A. van den Dobbelsteen, Outdoor thermal comfort within five different urban forms in the Netherlands. Building and Environment, 2015. 83: p. 65-78.

35. Jamei, E., P. Rajagopalan, M. Seyedmahmoudian, and Y. Jamei, Review on the impact of urban geometry and pedestrian level greening on outdoor thermal comfort. Renewable and Sustainable Energy Reviews, 2016. 54: p. 1002-1017.

36. Santamouris, M., Using cool pavements as a mitigation strategy to fight urban heat island-A review of the actual developments. Renewable and Sustainable Energy Reviews, 2013. 26: p. 224-240.

37. Gago, E.J., J. Roldan, R. Pacheco-Torres, and J. Ordóñez, The city and urban heat islands: A review of strategies to mitigate adverse effects. Renewable and Sustainable Energy Reviews, 2013. 25: p. 749-758. 
38. Taleghani, M., M. Tenpierik, A. van den Dobbelsteen, and R. de Dear, Energy use impact of and thermal comfort in different urban block types in the Netherlands. Energy and Buildings, 2013. 67: p. 166-175.

39. Taleghani, M., M. Tenpierik, and A. van den Dobbelsteen, Energy performance and thermal comfort of courtyard/atrium dwellings in the Netherlands in the light of climate change. Renewable Energy, 2014. 63: p. 486-497.

40. Taleghani, M., M. Tenpierik, and A. Dobbelsteen, Environmental Impact of Courtyards- A Review and Comparison of Residential Courtyard Buildings in Different Climates. Green Building, 2012. 7(2): p. 113-136.

41. Oke, T.R., Boundary Layer Climates. 2002: Taylor \& Francis.

42. Hwang, Y.H., Q.J.G. Lum, and Y.K.D. Chan, Micro-scale thermal performance of tropical urban parks in Singapore. Building and Environment, 2015. 94, Part 2: p. 467-476.

43. National Environment Agency, NEA, Local Climatology, 2013, 10 June 2014. Retrieved 26 June 2016. Available from: http://www.nea.gov.sg/weather-climate/climate-information.

44. Feyisa, G.L., K. Dons, and H. Meilby, Efficiency of parks in mitigating urban heat island effect: An example from Addis Ababa. Landscape and Urban Planning, 2014. 123: p. 87-95.

45. Spronken-Smith, R.A. and T.R. Oke, The thermal regime of urban parks in two cities with different summer climates. International Journal of Remote Sensing, 1998. 19(11): p. 2085-2104.

46. Vidrih, B. and S. Medved, Multiparametric model of urban park cooling island. Urban Forestry \& Urban Greening, 2013. 12(2): p. 220-229.

47. Hardwick, S.R., R. Toumi, M. Pfeifer, E.C. Turner, R. Nilus, and R.M. Ewers, The relationship between leaf area index and microclimate in tropical forest and oil palm plantation: Forest disturbance drives changes in microclimate. Agricultural and Forest Meteorology, 2015. 201: p. 187-195.

48. Taleghani, M., D.J. Sailor, M. Tenpierik, and A. van den Dobbelsteen, Thermal assessment of heat mitigation strategies: The case of Portland State University, Oregon, USA. Building and Environment, 2014. 73: p. 138-150.

49. Coutts, A.M., E.C. White, N.J. Tapper, J. Beringer, and S.J. Livesley, Temperature and human thermal comfort effects of street trees across three contrasting street canyon environments. Theoretical and Applied Climatology, 2016. 124(1): p. 55-68.

50. Doick, K. and T. Hutchings. Air temperature regulation by urban trees and green infrastructure. 2013 13.07.2016]; Available from:

http://www.forestry.gov.uk/pdf/FCRN012.pdf/\$FILE/FCRN012.pdf.

51. Monteith, J. and M. Unsworth, Principles of Environmental Physics: Plants, Animals, and the Atmosphere. 2013: Elsevier Science.

52. Mohr, H., G. Lawlor, D.W. Lawlor, and P. Schopfer, Plant Physiology. 2012: Springer Berlin Heidelberg.

53. Mayer, H., S. Kuppe, J. Holst, F. Imbery, and A. Matzarakis, Human thermal comfort below the canopy of street trees on a typical Central European summer day, in 5th Japanese-German Meeting on Urban Climatology, H.M.a.A. Matzarakis, Editor. 2008: Albert-Ludwigs-University of Freiburg, Germany October 2008.

54. Heisler, G.M., Special Issue Ecology of the Urban Forest IIEffects of individual trees on the solar radiation climate of small buildings. Urban Ecology, 1986. 9(3): p. 337-359.

55. Santamouris, M., Cooling the cities - A review of reflective and green roof mitigation technologies to fight heat island and improve comfort in urban environments. Solar Energy, 2014. 103: p. 682-703. 
56. Smith, K.R. and P.J. Roebber, Green Roof Mitigation Potential for a Proxy Future Climate Scenario in Chicago, Illinois. Journal of Applied Meteorology and Climatology, 2011. 50(3): p. 507-522.

57. The Weather Research \& Forecasting Model. 2016 [cited 2016; Available from: http://www.wrfmodel.org/index.php.

58. Sun, C.Y., K.P. Lee, T.P. Lin, and S.H. Lee, Vegetation as a Material of Roof and City to Cool down the Temperature. Advanced Materials Research, 2012. 461: p. 552-556.

59. Chen, H., R. Ooka, H. Huang, and T. Tsuchiya, Study on mitigation measures for outdoor thermal environment on present urban blocks in Tokyo using coupled simulation. Building and Environment, 2009. 44(11): p. 2290-2299.

60. Chen, H., R. Ooka, K. Harayama, S. Kato, and X. Li, Study on outdoor thermal environment of apartment block in Shenzhen, China with coupled simulation of convection, radiation and conduction. Energy and Buildings, 2004. 36(12): p. 1247-1258.

61. Taleghani, M., D. Sailor, and G.A. Ban-Weiss, Micrometeorological simulations to predict the impacts of heat mitigation strategies on pedestrian thermal comfort in a Los Angeles

neighborhood. Environmental Research Letters, 2016. 11(2): p. 024003.

62. Bartfelder, F. and M. Köhler, Experimentelle untersuchungen zur function von fassadenbegrünungen. 1987: Dissertation TU Berlin 612S.

63. Wong, N.H., A.Y. Kwang Tan, Y. Chen, K. Sekar, P.Y. Tan, D. Chan, K. Chiang, et al., Thermal evaluation of vertical greenery systems for building walls. Building and Environment, 2010. 45(3): p. 663-672.

64. H. Taha, D. Sailor, and H. Akbari, High-albedo materials for reducing building cooling energy use. 1992. p. Medium: ED; Size: Pages: (73 p).

65. Akbari, H. and H.D. Matthews, Global cooling updates: Reflective roofs and pavements. Energy and Buildings, 2012. 55: p. 2-6.

66. Carter, T. and A. Keeler, Life-cycle cost-benefit analysis of extensive vegetated roof systems. Journal of Environmental Management, 2008. 87(3): p. 350-363.

67. Saiz, S., C. Kennedy, B. Bass, and K. Pressnail, Comparative Life Cycle Assessment of Standard and Green Roofs. Environmental Science \& Technology, 2006. 40(13): p. 4312-4316.

68. Sproul, J., M.P. Wan, B.H. Mandel, and A.H. Rosenfeld, Economic comparison of white, green, and black flat roofs in the United States. Energy and Buildings, 2014. 71: p. 20-27.

69. Wong, N.H., S.F. Tay, R. Wong, C.L. Ong, and A. Sia, Life cycle cost analysis of rooftop gardens in Singapore. Building and Environment, 2003. 38(3): p. 499-509.

70. Taleghani, M., M. Tenpierik, and A. van den Dobbelsteen, Indoor thermal comfort in urban courtyard block dwellings in the Netherlands. Building and Environment, 2014. 82: p. 566-579.

71. Jaffal, I., S.-E. Ouldboukhitine, and R. Belarbi, A comprehensive study of the impact of green roofs on building energy performance. Renewable Energy, 2012. 43(0): p. 157-164.

72. Givoni, B., Man, climate and architecture. 1976: Applied Science Publishers.

73. Oke, T.R., Boundary Layer Climates. 1987, New York: Routledge.

74. Bretz, S., H. Akbari, A.H. Rosenfeld, and H. Taha, Implementation of Solar Reflective Surfaces: Materials and Utility Programs, in LBL Report 32467. 1992: University of California, Berkeley.

75. Santamouris, M., Environmental Design of Urban Buildings: An Integrated Approach. 2012: Taylor \& Francis.

76. Campra, P., M. Garcia, Y. Canton, and A. Palacios-Orueta, Surface temperature cooling trends and negative radiative forcing due to land use change toward greenhouse farming in southeastern Spain. Journal of Geophysical Research: Atmospheres, 2008. 113(D18): p. n/a-n/a.

77. Google Maps. 2016 25.07.2016]; Available from: https://www.google.com/maps. 
78. Rosenfeld, A.H., H. Akbari, S. Bretz, B.L. Fishman, D.M. Kurn, D. Sailor, and H. Taha, Mitigation of urban heat islands: materials, utility programs, updates. Energy and Buildings, 1995. 22(3): p. 255-265.

79. Doulos, L., M. Santamouris, and I. Livada, Passive cooling of outdoor urban spaces. The role of materials. Solar Energy, 2004. 77(2): p. 231-249.

80. Rosenfeld, A.H., H. Akbari, J.J. Romm, and M. Pomerantz, Cool communities: strategies for heat island mitigation and smog reduction. Energy and Buildings, 1998. 28(1): p. 51-62.

81. Taleghani, M. and U. Berardi, The effect of pavement characteristics on pedestrians' thermal comfort in Toronto. Urban Climate, Under review.

82. Carnielo, E. and M. Zinzi, Optical and thermal characterisation of cool asphalts to mitigate urban temperatures and building cooling demand. Building and Environment, 2013. 60: p. 56-65.

83. Arthur, H.R., J.R. Joseph, A. Hashem, and C.L. Alan, Painting the Town White-and Green. MIT Technology Review, 1997. 100(2). 